\title{
Incidental Catch and New Distributional Records of Asteroids by Bottom Trawling Activities from Southeast Coast of India
}

\author{
K. Chamundeeswari*, S. Saranya, S. Shanker, D. Varadharajan, S. Rajagopal and T. Balasubramanian \\ Faculty of Marine Sciences, Centre of Advanced Study in Marine Biology, Annamalai University, Parangipettai-608 502, Tamil Nadu, India
}

\begin{abstract}
A study was undertaken for a period of one year between January 2011 and December 2011 from Parangipettai coastal waters (Mudasalodai and Annankoil) southeast coast of India. Present study discusses the distribution and systematic position of asteroids from these study areas. There are 8 species viz., Luidia maculate (15.6\%), Astropecten indicus (54.9\%), A. hemprichi (6.9\%), Stellaster equestris (21.7\%) and Anthenea pentagonula (0.1\%), Protoreaster linki $(0.2 \%)$, Pentacerasterr regulus $(0.1 \%)$ and $P$. affinis $(0.2 \%)$ was observed. 4 species viz., Luidia maculata, Astropecten indicus, A. hemprichi, Stellaster equestris are commonly available in both stations, where as $P$. lincki and $P$. regulus observed only from station II and Anthenea pentagonula is newly recorded from station I. diversity indices of Shannon (H'), Simpson (1-D), Evenness, Mergalef's species richness and cluster analysis, MDS also derived based on the number of observed species. Species diversity, abundance, richness and evenness are higher in station I than the station II. The present study concluded that station I has higher resources of asteroids $(89.1 \%)$ than station II $(10.9 \%)$ and this study also provides additional information about diversity of asteroids.
\end{abstract}

Keywords: Abundance; Trash fish; A. pentagonula; Diversity; Shallow waters; Intertidal

\section{Introduction}

Asteroidea is one of the five main classes in the phylum Echinodermata. Representatives of them are commonly called as sea stars or star fishes are marine pentaradiate with the bilateral ancestors comprising of 1890 extant species under 36 families [1] and about 180 species of asteroids are prevailing in Indian waters including Andaman and Nicobar Islands [2]. Sea stars exists in ecosystems of sea grass, coral, rocky substratum etc. from shallow to deepest region in the ocean which shows different feeding modes like predators of small invertebrates (paxillosids), detritivores (valvatidans), planktivores (brisingids) and coral polyps eaters [3]. They play an important role in ecology as an indicator of fishing intensity, biomarkers for pollution [4]. They act as key species due to their predatory nature and they are documented as determining factors in patterns of distribution, abundance and diversity within low intertidal habitats $[5,6]$. They widely used in the developmental and experimental studies and used as model organism in the area of community structure and feeding ecology $[7,8]$. The recent threat for sea stars is habitat destruction and ocean acidification. Habitat destruction is the major threat to the sea star species those has restricted distribution. Sea stars live on the rocky substrates are very susceptible to increase of sand and silt deposition. Coastal development such as jetties and breakwaters which alter the shoreline and changing water currents will cause deposition of sand and silt. Deterioration of sea grass habitat by pollution will affect the some herbivorous sea stars. For specific algal feeding sea stars, changes in water quality or nutrients may susceptible to those feed on particular algae. Collection of sea stars for aquarium keeping also one of the threats for species decline for e.g. Patiriella vivipaara, Smilasterias tasmaniae and Marginaster littoralis are restricted to Tasmania and there are considered as threatened species. Ocean acidification is another serious threat to sea stars because they required calcium carbonate in the form of high magnesium calcite for construction of skeleton. Magnesium calcite is more soluble and sensitive to ocean acidification than the other calcite forms [9]. Studies on the biology or other related work of sea stars are scarce from Indian waters. Some lucid contribution on taxonomy was done by [10-25]. The knowledge on asteroids occurrence is poorly known from these coastal areas, hence, the present survey was undertaken to know abundance and distribution of asteroids through incidental catch along the Parangipettai coastal waters, southeast coast of India.

\section{Materials and Methods}

\section{Description of the study area}

Samples were collected from Parangipettai specifically at

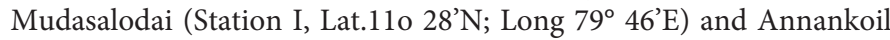
(Station II, Lat. $11^{\circ} 29^{\prime} \mathrm{N}$; Long. $79^{\circ} 46^{\prime} \mathrm{E}$ ) fish landing centre during the study period from January 2011 to December 2011. Station I \& II (Figure 1) is a small coastal fishing village $15 \mathrm{~km}$ south of Periyakuppam and it is merely closer to the marine biological station of Annamalai University. In station I, about 82 small trawlers and 15 non-motorized catamarans are engaged in regular fishing activity. Shrimp trawl net, fish trawl net, crab net are the major gears being operated. Fish, shrimp, crab and squid are the main target fishing. It is carried out at the depths range of $5-35 \mathrm{~m}$. Sea bottom is muddy with enormous silt, received from the Vellar River. In station II, about 200 FRP motorized boat and 130 small motorized (Lambadi) are engaged in fishing. Gillnets (Kanangatha valai-58mm and Katuvalai-166-118mm) used for capturing commercial fishes like Mackerel, sardine, squid and shrimps etc.

\section{Sample collection}

Collected samples were brought to the laboratory where samples

${ }^{*}$ Corresponding author: K. Chamundeeswari, Faculty of Marine Sciences, Centre of Advanced Study in Marine Biology, Annamalai University Parangipettai-608 502, Tamil Nadu, India, Tel: 04144-243223; Fax: 04144243553; E-mail: cham_mercy@yahoo.co.in

Received June 10, 2013; Accepted October 04, 2013; Published October 15 2013

Citation: Chamundeeswari K, Saranya S, Shanker S, Varadharajan D, Rajagopal S, et al. (2013) Incidental Catch and New Distributional Records of Asteroids by Bottom Trawling Activities from Southeast Coast of India. J Aquac Res Development 4: 198 doi:10.4172/2155-9546.1000198

Copyright: ( 2013 Chamundeeswari K, et al. This is an open-access article distributed under the terms of the Creative Commons Attribution License, which permits unrestricted use, distribution, and reproduction in any medium, provided the original author and source are credited. 
Citation: Chamundeeswari K, Saranya S, Shanker S, Varadharajan D, Rajagopal S, et al. (2013) Incidental Catch and New Distributional Records of Asteroids by Bottom Trawling Activities from Southeast Coast of India. J Aquac Res Development 4: 198 doi:10.4172/2155-9546.1000198

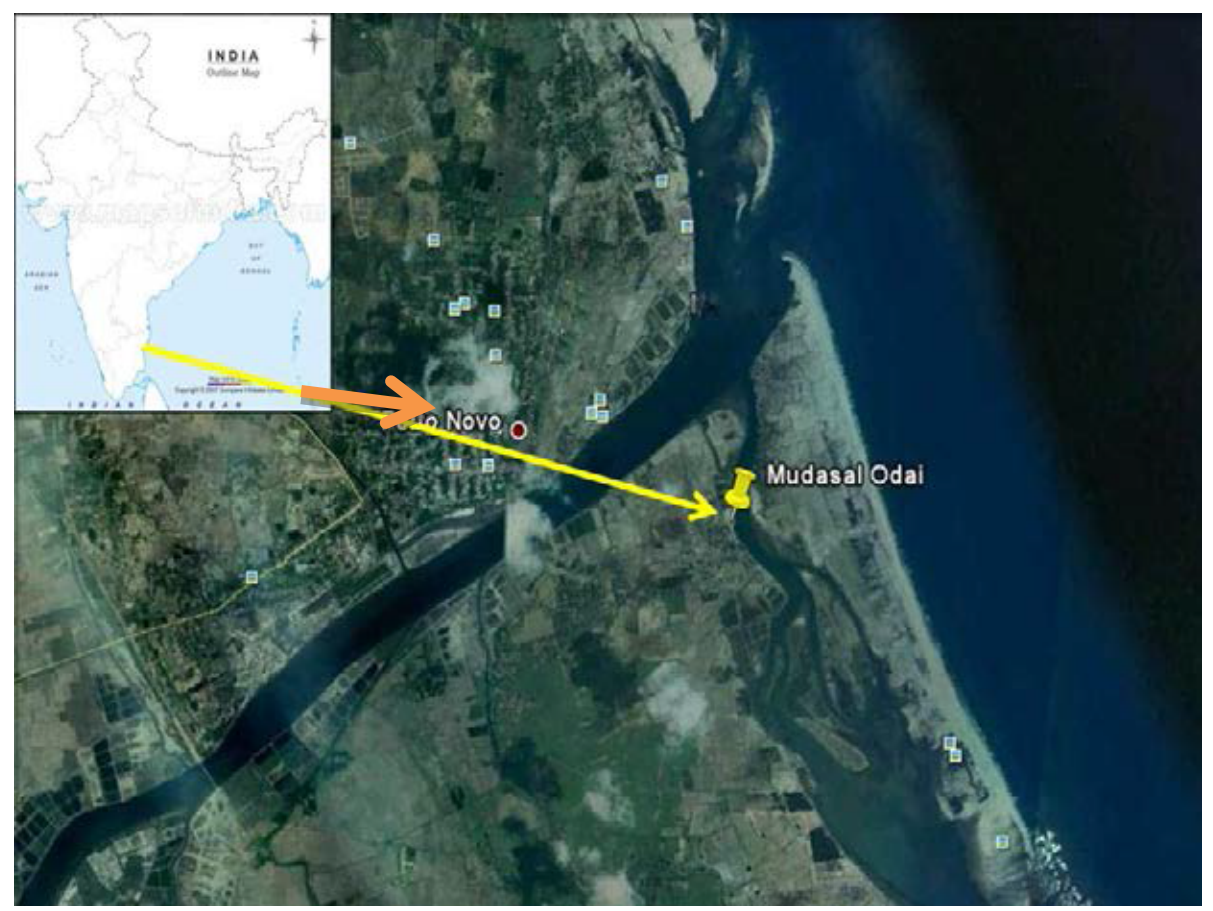

Figure 1: Map showing the study area Mudasalodai (Station I) and Annan koil (Staion II).

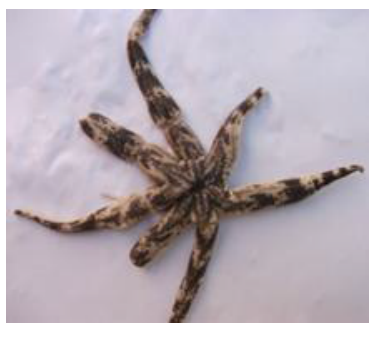

1. Luidia maculate

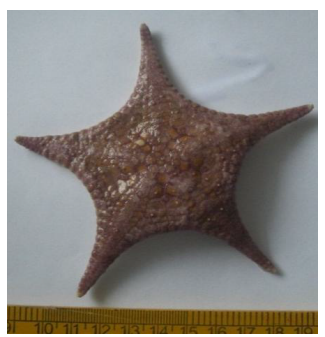

4. Stellaster equestris

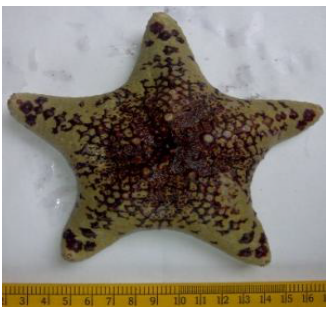

7. Pentaceraster regulus

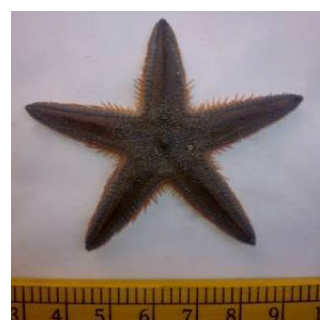

2. Astropecten indicus

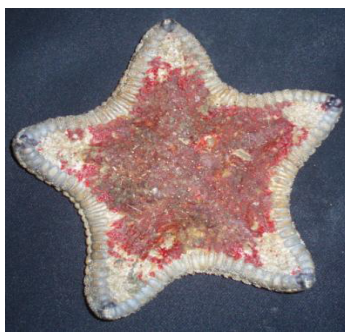

5. Anthenea pentagonula

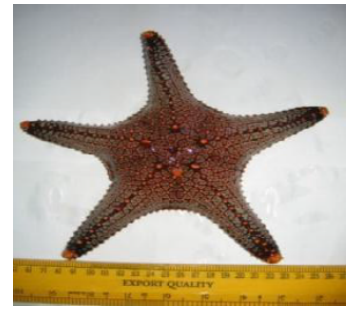

8. P. affinis

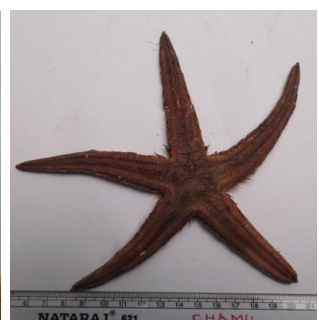

3. A. hemprichi

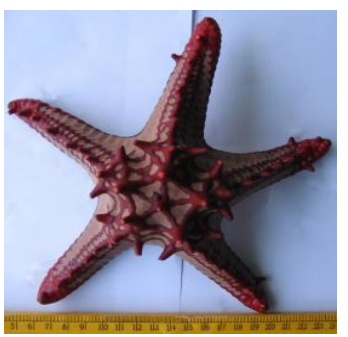

6. Protoreaster lincki

Plate 1: Species composition. 


\begin{tabular}{|c|c|c|c|c|}
\hline S. No & Species & Station I & Station II & Total \\
\hline $\mathbf{1}$ & Luidia maculata & 101 & 25 & 126 \\
\hline $\mathbf{2}$ & Astropecten indicus & 426 & 17 & 443 \\
\hline $\mathbf{3}$ & A. hemprichi & 37 & 19 & 56 \\
\hline $\mathbf{4}$ & Stellaster equestris & 151 & 24 & 175 \\
\hline $\mathbf{5}$ & Anthenea pentagonula & 1 & 0 & 1 \\
\hline $\mathbf{6}$ & Protoreaster lincki & 0 & 2 & 2 \\
\hline $\mathbf{7}$ & Pentaceraster regulus & 0 & 1 & 1 \\
\hline $\mathbf{8}$ & P. affinis & 2 & 0 & 2 \\
\hline Total & & $\mathbf{7 1 8}$ & $\mathbf{8 8}$ & $\mathbf{8 0 6}$ \\
\hline
\end{tabular}

Table 1: Distribution of sea stars along the two stations of landing centers in the Parangipettai (Mudasalodai and Annankoil) south east coast of India.

\section{Percentage composition $(\%)$}

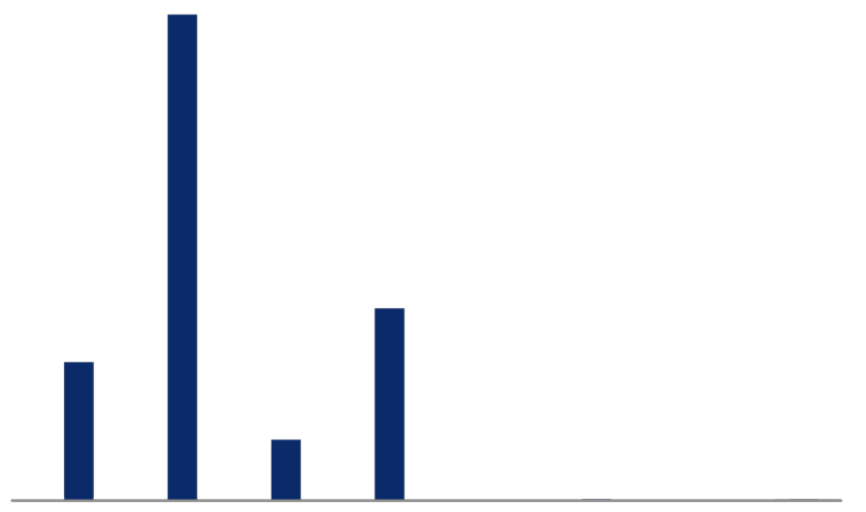

Figure 2: Total percentage (\%) contibution of sea stars.

\section{Stationwise percentage composition $(\%)$}

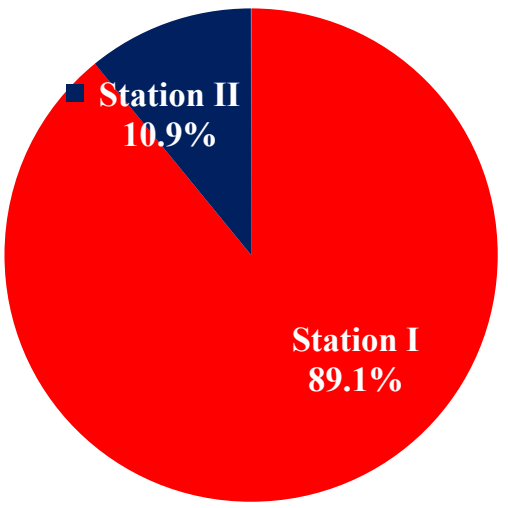

Figure 3: Distribution of sea stars among the two stations.

cleaned with water to remove adhered mud and other particles then identified them based on the morphology, spines in the abactinal (including supero-marginals, disc, radial arms, paxillae) actinal (infero-marginals, adambulacral, adoral)with the help of appropriate literature [10]. Data were collected fortnightly, pooled seasonally and this was repeated throughout the study period.

\section{Statistical software used}

The univariate methods such as Diversity indices of Shannon $(\mathrm{H}$ index), species richness indices of Mergalef index $(d)$, Simpson (1-D) and evenness index were used for estimation of relative abundances of different species of sea stars for four seasons. The multivariate methods of classification (Bray-Curtis cluster analysis) and ordination (nonmetric multidimensional scaling ordinations $\{$ MDS $\}$ ) was analyses by using software PRIMER version6 for assessing the relative importance in terms of abundance.

\section{Results}

\section{Species composition}

Totally 806 individuals of 8 species such as Luidia maculata, Astropecten indicus, A. hemprichi, Stellaster equestris, Anthenea pentagonula, Protoreaster lincki, Pentaceraster regulus and P. affinis (plate I) from 6 genera under 2 orders viz., Paxillosida and Valvatida were noticed at station I and II (Table 1). Species composition was varied among the observed study area. Maximum of 426 individuals were observed for $A$. indicus at station I and minimum of 1 for $A$. pentagonula station I.

\section{Percentage contribution}

The highest percentage of 55 was given by $A$. indicus during the survey, followed by $21.7 \%$ for S. equestris and $15.6 \%$ for L. maculata. The lowest of $0.1 \%$ was set by both $P$. regulus and $A$. pentagonula respectively (Figures 2 and 3).

\section{Taxonomic description of species}

\section{Luidia maculate Muller \& Troschel, 1842}

Synonyms: Luidia maculate and Luidia varia

Material examined: 10 specimens from station I and 4 from station II were examined.

Description: Rays 7 much elongated and cylindrical; $\mathrm{R} / \mathrm{r}$ ranged from $90-100 / 8.0-8.2 \mathrm{~mm}$ and arm breadth (br) $8.0-8.2 \mathrm{~mm}$. Disc flat, margins raised with the distinct rows of paxillae. No prominent supero-marginal plates. Abactinal plates with distinct paxillae arranged in 5-6 transverse rows arranged along the arms. The disc arrangement confused centrally. Paxillae are well spaced and square or rectangular at proximal and rounded, consisted at distal. Single series of actinal plates between infero-marginals and adambulacrals. Stalked pedicellariae found enormously on oral side.

Habitat: Sandy bottoms in bay, lagoon or in the deep reef, benthic, bentho pelagic and coastal.

Color: Creamy-white bars and blotches interspersed with brown bands on the aboral and creamy on the oral side.

Geographical distribution: Commonly distributed in the IndoPacific region.

Remarks: Alternative bold color patterns of dark and whitish plates on aboral are very clear in all the specimens. We observed species with 7 arms only. No marked madreporite. Stalked bivalve pedicellariae are numerous along the adambulacrals. All the specimens were with lost and degenerating arms. Dissection of adult specimen showed presence of bifurcated ampullae. Tube feet pointed. Clark HES et al. [26] reported that $L$. varia is the synonymy of $L$. maculata. This species is differing from L. magnifica by having 9-10 arms.

\section{Astropecten indicus Doderlein, 1888}

Common name: Fringed starfish

Synonyms: Astropecten indicus

Material examined: 12 specimens from station I and 5 from station II were observed. 
Description: Arms 5, R/r ranged between 32-40/10-13 mm and br: 9-12 mm. No anus instead involuted cone like structure at disc centre. Paxillae regularly arranged along the dorso-lateral arm with single row of dark stripes between it. Supero-marginal plates mostly 22, well developed and without spines but bearing alternatively arranged simple granules throughout. Infero-marginal plates with single series of spines and plates were extended to the adambulacrals. Two actinal plates were observed at the interradial region. Inter actinal region with spines. Ambulacral groove bordered with two rows of spines and adambulacral spines larger than the furrow spines. Tube feet pointed arranged in a single row on either side of the ambulacral ridge.

Habitat: Subtidal sandy, detritus and muddy bottoms often burrowing into the sea bottom.

Color: Greyish or muddy color on the aboral and creamy on the oral.

\section{Distribution: Tropical Indo-Pacific.}

Remarks: They generally inhabit sandy and muddy substrate. Stomach was always filled with bivalves and gastropods. Relative lengths of arms are the unique character of this species. Superomarginal plates without spines but bears alternatively arranged two series of tiny tubercles towards arm tip. This species is available in a larger quantity throughout the year.

\section{Astropecten hemprichi Muller \& Troschel, 1842}

Synonyms: Astropecten hemprichi, Astropecten articulates and Astropecten mauritianus.

Material examined: 6 from station I and 4 from station II were examined.

Description: Arms 5 four times longer than the central disc, $\mathrm{R} / \mathrm{r}$ : 91-102/20-22mm and br: $18-20 \mathrm{~mm}$. Supero-marginal plates were numerous and no spines at the first four plates. About 15paxillae at each inter radius between the basal supero-marginal plates are distinct. Brown color alternative bands along the inter radius and edges of arms are clearly seen in juveniles. Single series of short spinelets found at the inner end of supero-marginal plates. Single series of enlarged spines found along the infero-marginal spines and also backed with numerous small spines. Two series of adambulacral spines and the inner are more elongated.

\section{Habitat: Sandy bottom}

Color: Brownish on aboral

Distribution: Aldabra, Eastern Africa and Madagaskar, Mauritius, Mozambique, Red sea, Seychelles, South Africa, Tanzania, Bay of Bengal, Arabian Sea, West Indian Ocean.

Remarks: Young ones are more fragile and distinguish from adult by bearing stripes along interradius. Sastry DRK [25] described that, specimens lake supero-marginal spines instead, short conspicuous and conical spines are observed.

\section{Stellaster equestris Retzius, 1805}

Synonyms: Asterias equestris, Stellaster childreni, Stellaster equestris childreni, Stellaster equestris, Stellaster incei and Stellaster belcheri.

Material examined: 6 from station I and 5 from station II were observed.

Description: Arm 5, shorter and narrower than disc. R/r: 60-
65/29-33 mm and br: 8-11 $\mathrm{mm}$. Center of the disc is slightly raised and arms flat. There is a small groove in each inter radius. Aboral plates are more or less round and are different sizes and covered by small granules. The median carinal plates are slightly elevated from the rest which carries 2-3 enlarged granules on each arm. Inter radial plates adjacent to the supero-marginal plates are slightly elevated. The first few infero-marginal plates are small and oval in shape, remaining plates are almost square shaped and flat. Each infero-marginal plates bear a peculiar type of single series of spines. Actinal plates are small, rounded fewer in number and gives smooth texture. The adambulacral armature consists of two rows of spines. The outer row consists of single spine at the centre, a pedicellariae at the proximal and an enlarged granule at the distal end. The second row consists of 6 short flat spines of which the middle ones are the largest.

Remarks: This species is more distinguished from other species by having unique polygonal plates on oral and aboral side. Clark AM [10] stated that, juvenile specimen of Goniodiscaster have smooth, even granulation like Stellaster.

\section{Habitat: Sandy and muddy environments}

Color: Purple on aboral purplish with creamy white on oral side

\section{Anthenea pentagonula Lamarck, 1816}

Synonyms: Asterias pentagonula, Anthenea pentagonula, Anthnea rudis and Anthenea tuberculata.

Material examined: Only one specimen from station I.

Description: Arm 5 shorter and broad at base. Disc is wider. $\mathrm{R} / \mathrm{r}$ : 75/45 mm, br: $43 \mathrm{~mm}$. Body pentagonal, edges are stretched by prominent and vertically placed well developed supero-marginal plates. Disc larger, skin is thick which bears spinelets and granules. The carinals are slightly raised. Wider interradials, all supero and inferomarginal plates are stacked with each other and engraved with thick granules. Numerous large bivalved pedicellariae scattered on oral side are interesting characters of this species.

Habitat: Sandy and muddy environments.

Color: Reddish on pentagonal aboral and the rest of the body with pale color.

Geographical distribution: Gulf of Mannar, Andaman and Nicobar Islands and tropical Indo-west Pacific regions.

Remarks: Remarkable point is that few bristles like a structure may be of parasites exposed on the aboral surface of this species.

\section{Protoreaster lincki Blain ville, 1830}

Common name: African Red-Knob sea star; Red Knob; Red Spine Star; Crimson Knobbed Star Fish; African Sea Star.

Synonyms: Asterias lincki, Oreaster linckii, Pentaceros lincki, Pentaceros muricatus, Oreaster muricatus, Oreaster reinhartdi.

Material examined: Only two specimens were observed from station II.

Description: Arm 5, elongated from the disc and triangular, $\mathrm{R} / \mathrm{r}$ : $120-114 / 35-39$ and br: $38-42 \mathrm{~mm}$. disc raised upwardly, plates reticulated, angular inter radius, single central spine near anus, single spine on each primary plate and 3 on secondary plates. Spines are stout with pointed tips. Carinal spines are stout and shorter than primary one. Either lateral side towards arm tip of adult specimen has 3 lateral spines. Bivalve pedicellariae are more scattered on oral side. 
Habitat: Coral and sea grass environment

Color: Pinkish on grey background on aboral and fully pinkish on oral

Geographical distribution: Southeast Arabia, Ceylon, Bay of Bengal, East Indies, Australia, western and central Indian Ocean.

Remarks: One of the dissected specimens had shown disc type tube feet and it was pinkish from the podia and bifurcated ampullae whitish. Clark AM [10] mentioned that, Pentaceraster alveolatus superficially resembles Protoreaster lincki in the development of abactinal and supeo-marginal spines but differs in having infero-marginal spines.

\section{Pentaceraster regulus Muller \& Troschel, 1842}

\section{Synonyms: Pentaceros regulus, Pentaceros australis}

Material examined: Three specimens were observed from Station II.

Description: Arm 5, relatively short \& narrow, disc enlarged, $\mathrm{R} / \mathrm{r}$ : 70-90/35-45 $\mathrm{mm}$ and br: 25-39 $\mathrm{mm}$, dorsal armament found only on the disc. Elevations and spines form regular longitudinal series. Dorso lateral elevations or spines developed along the arm rarely few in number. No inter radial supero-marginal spines. Valvate type of pedicellariae distributed on the actinal surface only. Tube feet disc type. Ventro-lateral plates 3 rows and distinct.

Habitat: Sandy and muddy environments.

Color: Maroon on light or pale background.

Geographical distribution: Bay of Bengal, East Indies, North Australia, Philippine, China, south Japan and South Pacific Islands and Lakshadweep to western Pacific Ocean.

Remarks: Clark AM [10] mentioned, $P$. regulus and P. gracilis has similar appearance. Karuppaiyan M [27] stated that this species shows remarkable color patterns like bluish, greyish, yellowish.

\section{Pentaceraster affinis Muller \& Troschel, 1842}

Synonyms: Pentaceros affinis and Pentaceraster affinis.

Material examined: Two specimens were observed from station I.

Description: Arm 5, R/r: 95-110/ 48-55 mm and br: 50-53 mm. This species is looks similar like $P$. regulus, but it is differ by its dorso lateral armament on the entire aboral surface. Abactinal plate more reticulated, small pedicellariae were scattered over on it. Porous are

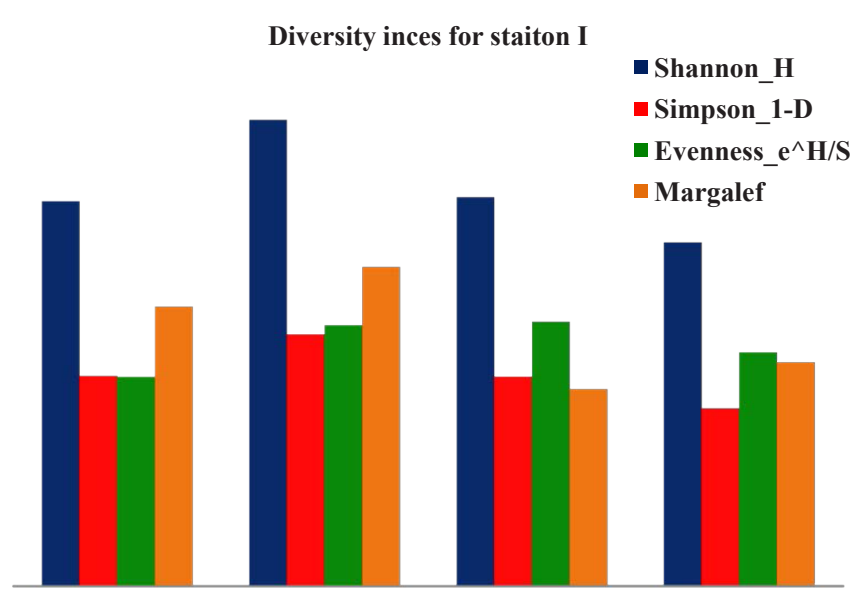

Figure 4: Diversity indices for station I.

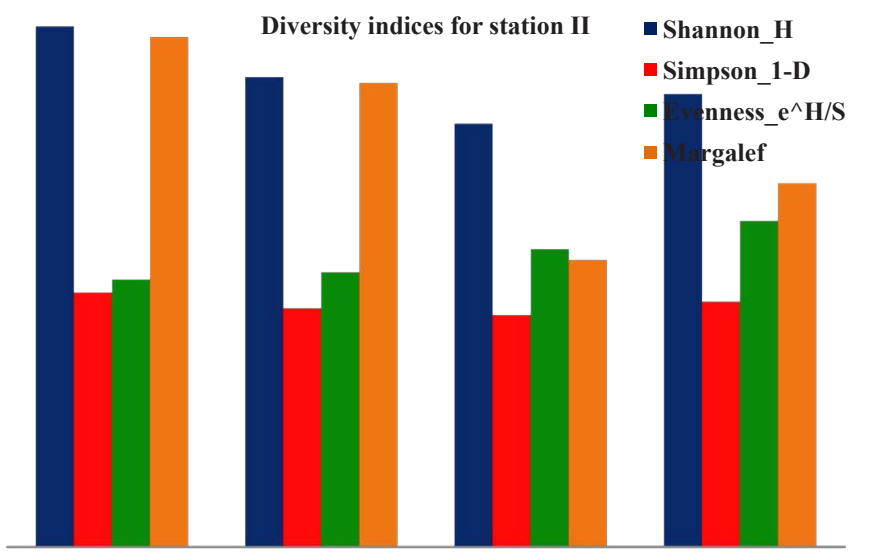

Figure 5: Diversity indices for station II.

contained approximately 50 pores per each area. Single tubercleon each supero-marginals, spinelets were grouped on infero-marginals. Primary, carinal and latero-ventral tubercles stouter and were relatively smaller. Armsmore or less elongated. Inter marginal plate present between inter radial infero and supero-marginal plates. Abactinal armaments also spinulated.

Habitat: Sandy

Color: Maroon patches on grey background

Geographical distribution: Tropical Indo-west Pacific

Remarks: This species has similarity with $P$. mammillatus by having aboral reticulated patterns and tubercles.

\section{Diversity indices}

Season wise contribution: The maximum of 275 individuals were accounted during pre monsoon and minimum of 103 during summer at station $\mathrm{I}$ and it was 31 during pre monsoon and 15 during monsoon at station II. The Shannon index (H') showed maximum value of 1.262 during summer and minimum 0.9294 during monsoon at station I and it was 1.585 during post monsoon \& 1.288 on pre monsoon at station II. The higher value for Simpson (1-D) index was 0.6821 on summer and minimum of 0.4815 on monsoon for station I and 0.7744 during post monsoon \& 0.7055 pre monsoon for station II. Evenness $(\mathrm{eH} / \mathrm{S})$ showed maximum of 0.716 at pre monsoon and minimum of 0.5667 at post monsoon from station I and 0.993 during monsoon and 0.8136 during pre monsoon at station II. Likewise, the higher value of Margalef index for station I \& II was0.863 (summer), 1.553 (post monsoon) and minimum 0.5341 (pre monsoon) \& 0.8736 during pre monsoon respectively (Figures 4 and 5).

Cluster analysis: At station I, the cluster analysis showed only one group was formed by L. maculata and S. equestris at the level of $69 \%$ similarity (Figure 6). Three groups formed at station II (Figure 7). The first group is formed by linking L. maculata and S. equestris at the highest similarity level of $85 \%$, the second group is formed by $A$. indicus and $A$. hemprichi at $82 \%$ and third group by $P$. lincki and $P$. regulus at the level of 67\%.Similarity level for both the stations (Figure 8 ) showed three groups. First group formed by L. maculata and $S$. equestris at $82 \%$ level followed by two groups such as $A$. pentagonula, P. regulus, $P$. lincki and P. affinis formed at the level $66 \%$.

MDS: There are three clusters formed at the stress level 0 for station 


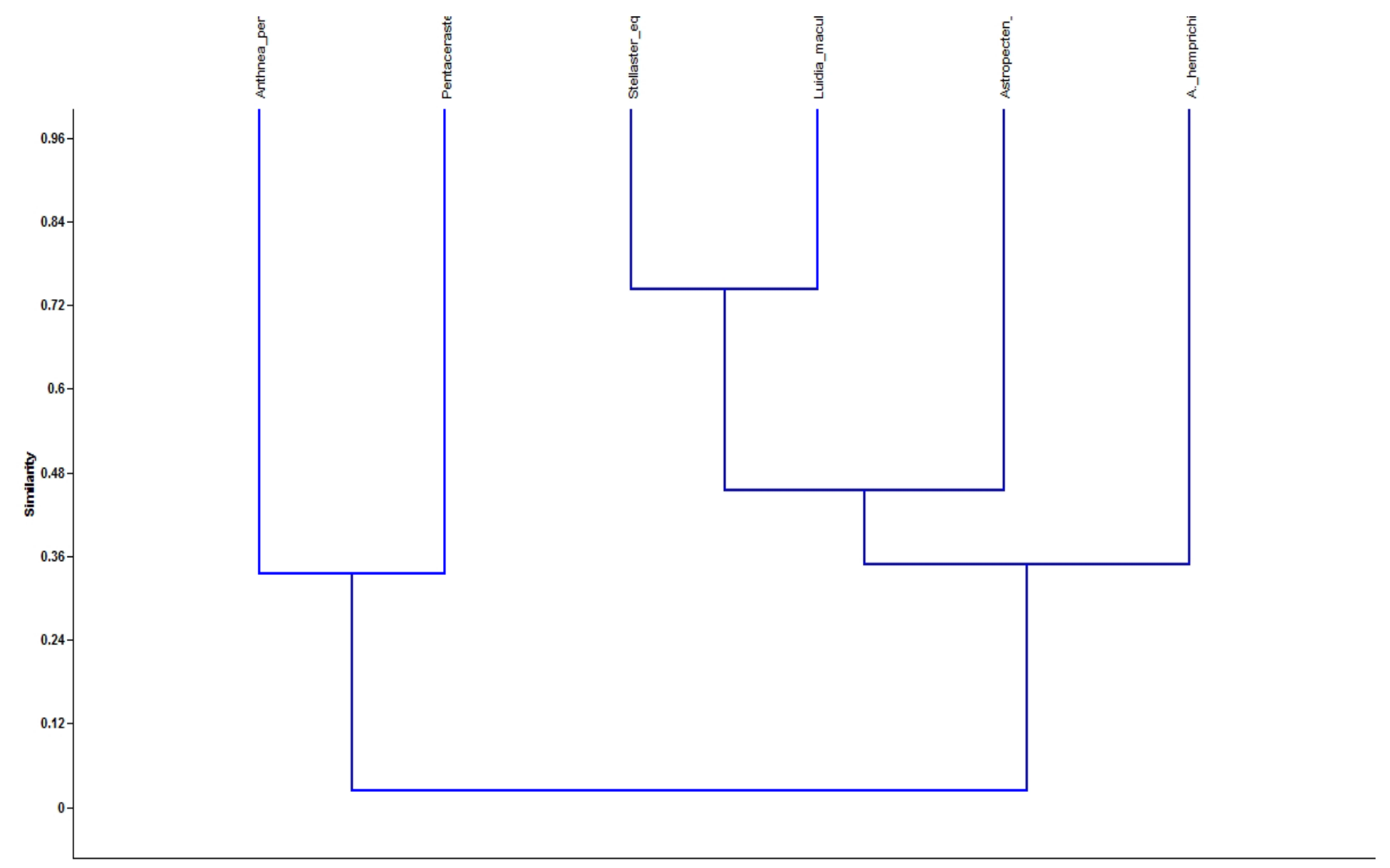

Figure 6: Dendrogram drawn for sea stars obtained from station I.

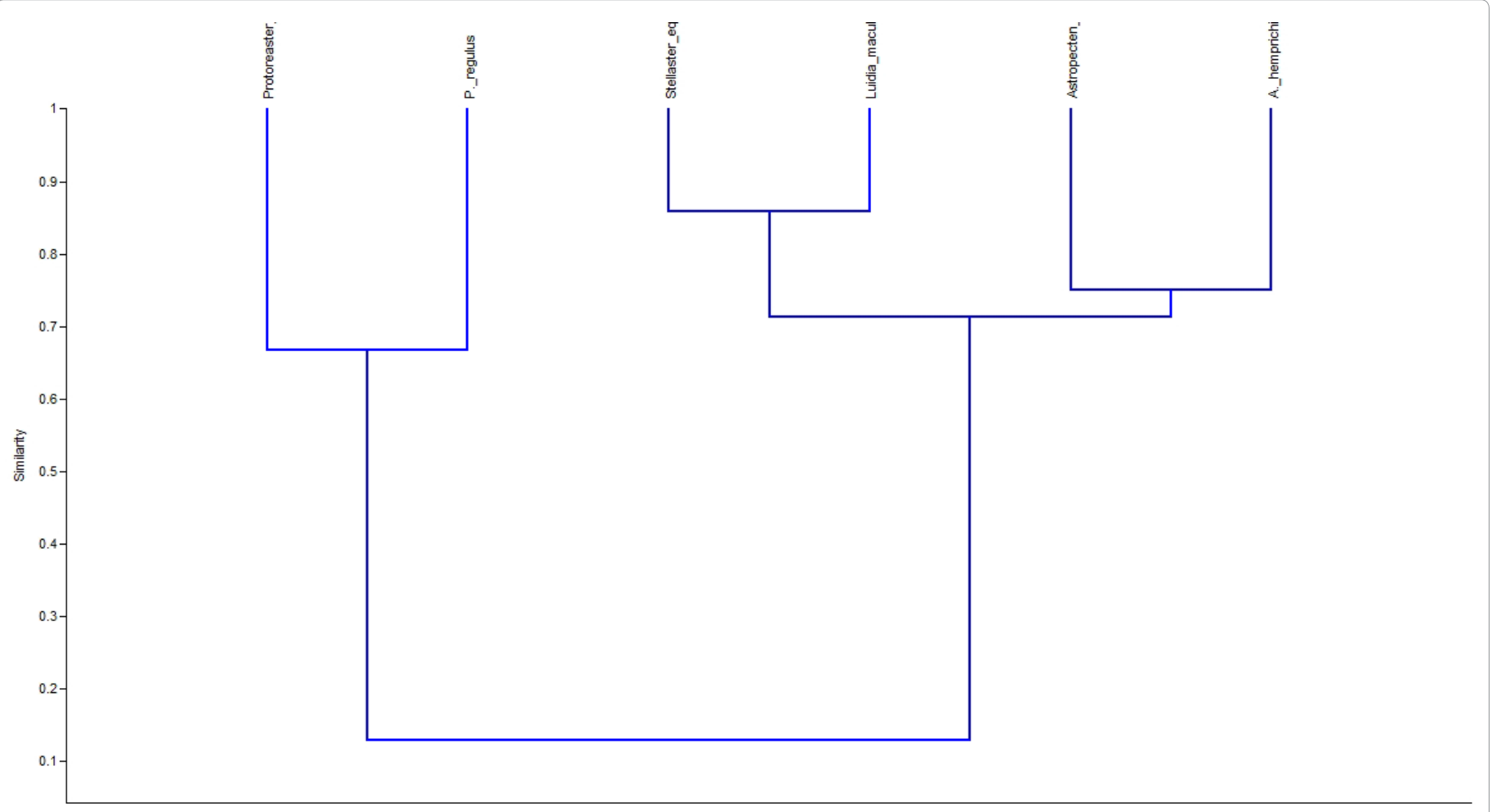

Figure 7: Dendrogram drawn for sea stars obtained from station II. 


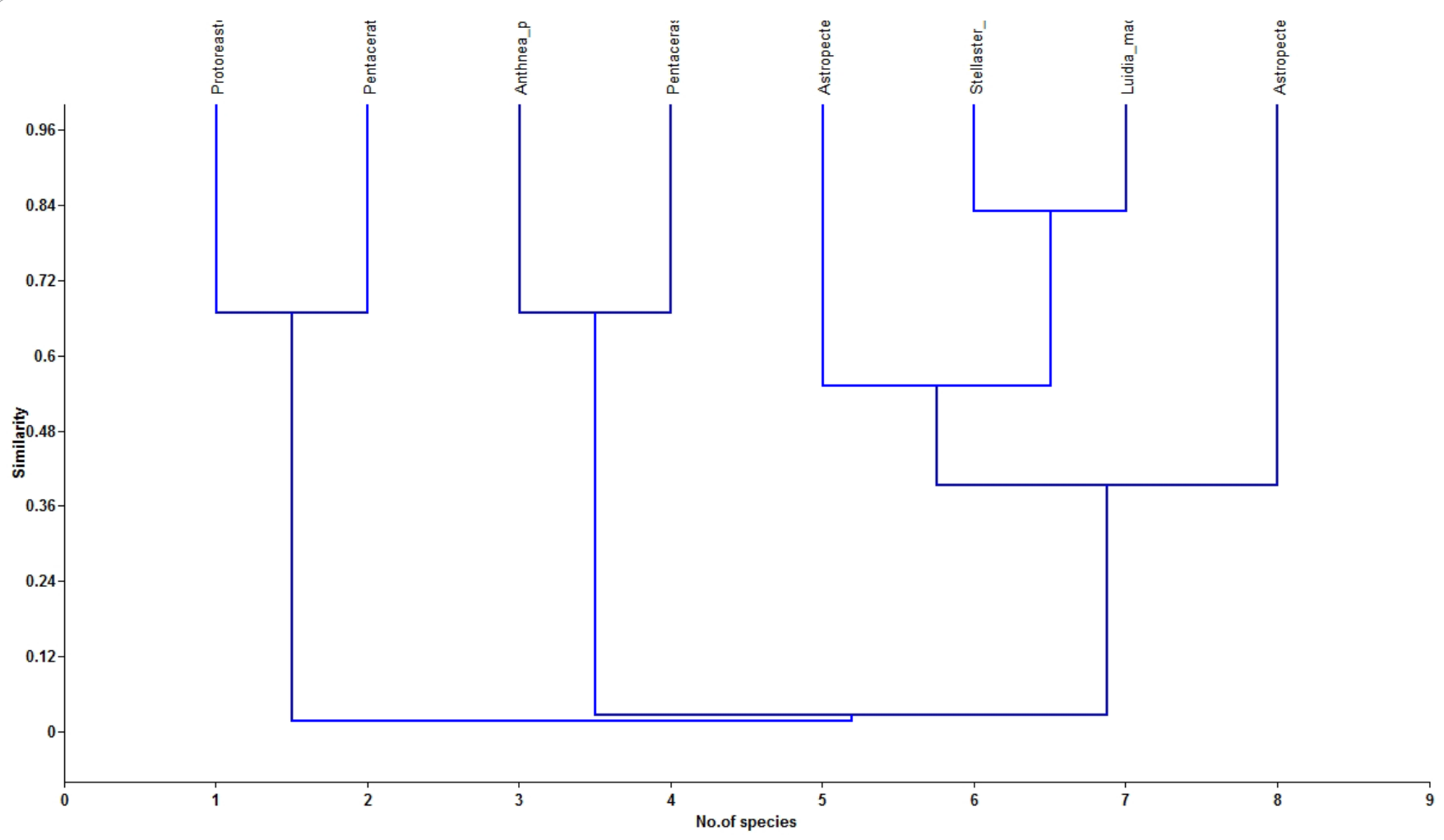

Figure 8: Dendrogram drawn for two stations.

Pentaceraster_affinis_

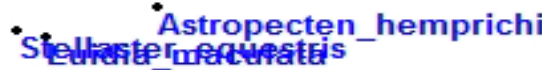

Astropecten_indicus

\section{Anthnea_pen}

Figure 9: MDS drawn for station I. 
'Stellaster_equestris

Luidia maculata

Pentacerater_

Astropecten_hemprichi

'Astropecten_indicus

Protoreaster_lincki

Figure 10: MDS drawn for station II.

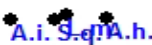

of Astropecten are found throughout the world in the intertidal and subtidal sandy environments. Clark HES et al. [26] also affirmed that, the large family Astropectenidiae has a worldwide distribution and is known from shallow subtitdal to greater depths. Sea star $P$. regulus and A. pentagonula is a shallow water sandy habitant, occasionally caught by trawl nets hence it's caught was minimum in both stations. The maximum occurrence was due to spawning during summer followed by catching of more juveniles during pre monsoon by bottom trawl from station I and catching of organisms by gillnets operation at station II. The minimum occurrence was due to fishing holidays at station I and due to monsoon at station II.

Species diversity is a simple and useful measure of a biological system [29]. The quantification of biodiversity is fundamental to the identification of changes that may take place to our understanding of their possible consequences and it can be measured of many levels and in different ways [30,31]. In the present study, the maximum diversity indices were noticed during summer at station I and minimum during monsoon. The same result was obtained to station II but the values were shifted to post monsoon and pre monsoon respectively. The Shannon and Simpson diversity was correlated with each other for station I. The low diversity obtained during the survey was monsoonal flood. Species evenness was more even on pre monsoon and lesser on post monsoon for station I, it was higher on monsoon \& lower on post monsoon for station II. The evenness for the macro benthos depends on the many environmental factors like habitat, food availability, migration etc. controls the distribution of sea stars. Mostly, the paxillosidans are found common on the shallow sandy and muddy areas but valvatididans found little deeper and sandy and reef environments. There is a general consideration that, the species are more or less equal to evenness when the benthic community undisturbed [32,33]. Richness of species also found higher during summer at station I \& on post monsoon at station II.

The taxonomic diversity is sum of biodiversity which is seen to be natural extension of a form of Simpson index, incorporating taxonomic (or phylogenetic) information since it mixes taxonomic relatedness with the evenness properties of the abundance distribution. The value of this univariate index appears not to be influence by sampling effort. The diversity measures derived in this study is based on the observation of number of sample only. The MDS 2 or 3D map of samples reflects the similarities of their biological communities, for example the species has clustered much closer have similar community structure and species are far apart have different level of abundance. The goodness of fit is measured by the stress value; an ideal representation having zero stress. Relative stress values increase with increasing number of entities and decreasing dimensions. The MDS ordinations derived in this present study revealed that, the same grouping of stations as in the cluster analysis. The stress values found in all the MDS configurations from the two stations were at 0 levels indicating good representation of the interrelationship between the different groups of sea stars in both stations.

Asteroids are a unique group of marine invertebrates which has more confusion in identifying species also this group is puzzle for zoologists and paleontologists. Very few works of it has been done so for in India and other neighboring countries, some most spectacular works were done by James DB and Sastry DRK [14-25], [34] from Indian waters. A remarkable work on the global trend of asteroid diversity by $\mathrm{Mah} \mathrm{CH}$ et al. [1] provides updated information on it. From this study, we conclude that, the Parangipettai coastal water has 8 different species of sea stars, amongst, 4 of them were common to both 
Citation: Chamundeeswari K, Saranya S, Shanker S, Varadharajan D, Rajagopal S, et al. (2013) Incidental Catch and New Distributional Records of Asteroids by Bottom Trawling Activities from Southeast Coast of India. J Aquac Res Development 4: 198 doi:10.4172/2155-9546.1000198

the stations and station I has high species abundance. Based on the number of species, the diversity is more in the station II even though this study provides some information on asteroids still, more study is needto understand the deeper water sea stars. This study provides sufficient taxonomical information about asteroids. This study also implies that this is the additional work for the existing work. The untargeted asteroid resources have to be utilized for human needs with sustainable management.

\section{Acknowledgements}

Authors are thankful to the authorities of Annamalai University for providing necessary facilities and to the Ministry of Earth Sciences, New Delhi, India for the financial assistance.

\section{References}

1. Mah CH, Blake DB (2012) Global Diversity and Phylogeny of the Asteroidea (Echinodermata). PLoS one 7: e35644.

2. Venkataraman K, Mohideen W (2005) Coastal and marine biodiversity of India I J Mar Sci 34: 57-75.

3. Cintra-Buenrostro CE, Reyes-Bonilla H, Herrero-Perezrul MD (2005) Oceanographic conditions and diversity of sea stars (Echinodermata: Asteroidea) in the Gulf of California, Mexico. Rev Biol Trop 53: 245-261.

4. Everaarts JM (1995) DNA integrity as a biomarker of marine pollution: Strand breaks in seastar (Asterias rubens) and dab (Limanda limanda). Mar Pollut Bull 31: 431-438

5. Lubchenco J, Menge BA (1978) Community Development and Persistence in a Low Rocky Intertidal Zone. Ecol Monogr 59: 67-94.

6. Menge BA (1982) Effects of feeding on the environment: Asteroidea. In: Echinoderm Nutrition, M Jangoux, JM Lawrence (eds.). Balkema, Netherlands. pp 521-551.

7. Menge BA, Daley BA, Lubchenco J, Sanford E, Dahlhoff E, et al. (1999) TopDown and Bottom-Up Regulation of New Zealand Rocky Intertidal Communities. Ecol Monogr 69: 297-330

8. Ortiz M, Jesse S, Stotz W, Wolff M (2003) Feeding behavior of the asteroid Meyenaster gelatinosus in response to changes in abundance of the scallop Argopecten purpuratus in northern Chile. Arch Hydrobiol 157: 213-225.

9. UNEP (2010) UNEP Emerging Issues: Environmental Consequences of Ocean Acidification: A Threat to Food Security.

10. Clark AM, Rowe FWE (1971) Monograph of shallow water Indo-west Pacific Echinoderms. Trustees of the British Museum (Natural History), London vii. p 238.

11. Sladen WP (1882) The Asteroidea of HMS Challenger Expedition, Part I Pterasteridae. J Linn Soc Zool 16: 186-246.

12. Sladen WP (1883) The Asteroidea of HMS Challenger Expedition, Part II Astropectinidae. J Linn Soc Zool 17: 214-269.

13. Sladen WP (1889) On the Asteroidea of the Mergui Archipelago, Collected for the Trustees of the Indian Museum, Calcutta by Dr. John Anderson, FRS Superintendent of the Museum. J Linn Soc 21: 319-331.

14. James DB (1997) Notes on the family Goniasteridae (Echinodermata: Asteroidea) from the Indian seas. J Mar Biol Ass India 38: 133-138.

15. James DB (1969) Catalogue of Echinoderms in the reference collections of the Central Marine Fisheries Research Institute, Mandapam. Bull Cent Mar Fish Res Inst 7: 51-62.

16. James DB (1972) Note on the development of the asteroid Asterina burton Gray. J Mar Biol Ass India 14: 883-884.

17. James DB (1973) Studies on Indian Echinoderms 5. New and little known Starfishes from the Indian Seas. J Mar Biol Ass India 15: 556-559.
18. James DB (1983) Research on Indian Echinoderms-A review. J Mar Biol Ass India 25: 91-108

19. James DB (1986) Zoogeography of the shallow-water Echinoderms of Indian seas. In: Recent Advances in Marine Biology, PSBR James (ed). Today and Tomorrow printers and publishers, New Delhi. pp 569-591.

20. James DB (1998) Echinodermata, B. In: Alfred JRB (Ed.) Faunal diversity in India. Zoological Survey of India Culcutta, I-VIII. Publisher - Envis Centre. pp 398-403.

21. Sastry DRK (1995) Asteroidea, Ophiuroidea and holothuroidea (Echinodermata). Zool. Surv. India. Estuarine Ecosystem Series. Part 2: Hugli Matla Estuary. 327-228.

22. Sastry DRK (1998) Echinodermata. Zool. Sur. Of India. Culcutta Fauna series 3: Fauna of West Bengal. Part 10: 463-489.

23. Sastry DRK (1999) Echinodermata of Great Nicobar Island, Bay of Bengal. J Andaman Sci Asso 15: 91-93.

24. Sastry DRK (1999a) New Records of Echinodermata from Andaman Islands. J Andaman Sci Ass 15: 17-20.

25. Sastry DRK (2001) Echinodermata. Zool. Surv. India. Estuarine Ecosystem Series 4, Fauna of Godavari Estuary. 83-84.

26. Clark HES, McKnight DG (2001) The marine fauna of New Zealand: Echinodermata: Asteroidea (Sea-stars). NIWA Biodiversity Memoir. p 196

27. Karuppaiyan M (2007) Diversity of Echinoderms along the southeast coast of India. Ph.D., Thesis. Faculty of Marine Sciences, Annamalai University, India. p 266

28. Wells FE, Lalli CM (2003) Astropecten sumbawanus (Echinodermata: Asteroidea) in Withnell Bay, northwestern Australia. In: The Marine Flora and Fauna of Dampier, Western Australia Western Australian Museum, Perth Wells, F. E., D. I. Walker \& D. S. Jones (eds.). pp 209-216.

29. Redding DW, Hartmann K, Mimoto A, Bokal D, DeVos M, et al. (2008) Evolutionarily distinctive species often capture more phylogenetic diversity than expected. J Theor Biol 251: 606-615.

30. Harper JL, Hawksworth DL (1994) Biodiversity: measurement and estimation. Philos Trans R Soc Lond B Biol Sci 345: 5-12.

31. May RM (1994) Biological Diversity: Differences between Land and Sea. Philos Trans R Soc B Biol Sci 43: 105-111.

32. Varadharajan D, Soundarapandian P, Gunalan B, Babu R (2010) Seasonal Abundance of Macro Benthic Composition and Diversity along the South East Coast of India. European J Appl Sci 2: 1-5.

33. Manoharan J, Varadharajan D, Thilagavathi B, Priyadharsini S (2011) Biodiversity and abundance of benthos along the South East Coast of India Advan Appl Sci Res 2: 554-562.

34. Radhadrishnan Y, Ganapati PN (1969) Fauna of Kakinada Bay. Bull Nat Inst Sci India 38: 689-699. 